\title{
Effect of the Organobentonite Filler on Structure and Properties of Composites Based on Hydroxyethyl Cellulose
}

\author{
Olga V. Alekseeva, Anna N. Rodionova, Nadezhda A. Bagrovskaya, \\ Alexander V. Agafonov, and Andrew V. Noskov \\ G. A. Krestov Institute of Solution Chemistry, Russian Academy of Sciences, Akademicheskaya Str. 1, Ivanovo 153045, Russia \\ Correspondence should be addressed to Andrew V. Noskov; avn@isc-ras.ru
}

Received 5 February 2017; Revised 11 June 2017; Accepted 4 July 2017; Published 14 September 2017

Academic Editor: María D. Alba

Copyright ( 2017 Olga V. Alekseeva et al. This is an open access article distributed under the Creative Commons Attribution License, which permits unrestricted use, distribution, and reproduction in any medium, provided the original work is properly cited.

Organobentonite powder was synthesized and characterized using laser diffraction, X-ray diffraction, low-temperature nitrogen adsorption-desorption technique, and dynamic light scattering. Obtained powder was found as material with mesopores. The organobentonite particles were larger than pure bentonite one. Hydroxyethyl cellulose (HEC) was filled with organobentonite particles by mechanical dispersion, and produced composite films were researched by the number of methods. New data relating to structure, tensile properties, and antimicrobial activity of HEC/organobentonite composites were obtained. Using results of Xray diffraction, the reflections assigned to crystal filler in polymer material were proved. Concentration effect of the filling agent on tensile properties of composite film was revealed. Data of infrared (IR) spectrometry indicated a decrease in the density of hydrogen-bond net in HEC/organobentonite composite as compared with pristine HEC. Using microbiological tests, it was found that the HEC/organobentonite films exhibited bacteriostatic action against $S$. aureus and fungistatic action against molds.

\section{Introduction}

In recent years, organic/inorganic composites have attracted much attention of researchers because of the perspective use of these materials in instrument engineering, electronics, building sector, food industry, medicine, and so on. Insertion of fillers results in modifying the pristine polymer matrix, which can lead to creation of materials with improved physical and chemical properties and the main service characteristics (mechanical, electrical). There are numerous publications devoted to the mechanical, optical, tribological, and thermochemical properties and structure of polymers containing different inorganic fillers [1-10].

Layered aluminosilicate is a commonly used material for the production of polymer composites [11, 12]. It has been used to enhance many properties of polymers such as modulus, thermal stability, flame retardancy, rheological behavior, and permeability [13]. The abundant montmorillonite (MMT) and bentonite (at least 70\% of MMT) clays show the greatest promise of the entire range of layered silicates $[14,15]$.
The MMT clay has a layered structure and excellent hydrophilic and cation exchange properties [14]. The MMT clay is composed of units made of two silica tetrahedral sheets centered with an alumina octahedral sheet, which is called $2: 1$ phyllosilicate and chemically it is a metal silicate. Its layers are stacked by weak dipolar or van der Waals forces, and it has both surface and edge charges [16]. Stacking of these layers generates van der Waals gaps or galleries. The galleries are occupied by the inorganic cations, such as $\mathrm{Na}^{+}, \mathrm{Ca}^{2+}$, and $\mathrm{Mg}^{2+}$. When the inorganic cations are exchanged with the alkylammonium cations, montmorillonite possesses a good compatibility with polymers [17-19].

Montmorillonite is widely used for the preparation of polymer composites. Recent research focuses on incorporating layered silicates, especially Na-MMT, that could be used as the reinforcing phase due to the latter's very high aspect ratio ( 100). Thus, with a very low loading of MMT (1-10\%), the produced nanocomposites exhibit up to tenfold increase in mechanical, thermal, electrical, and barrier properties [20, 21]. 

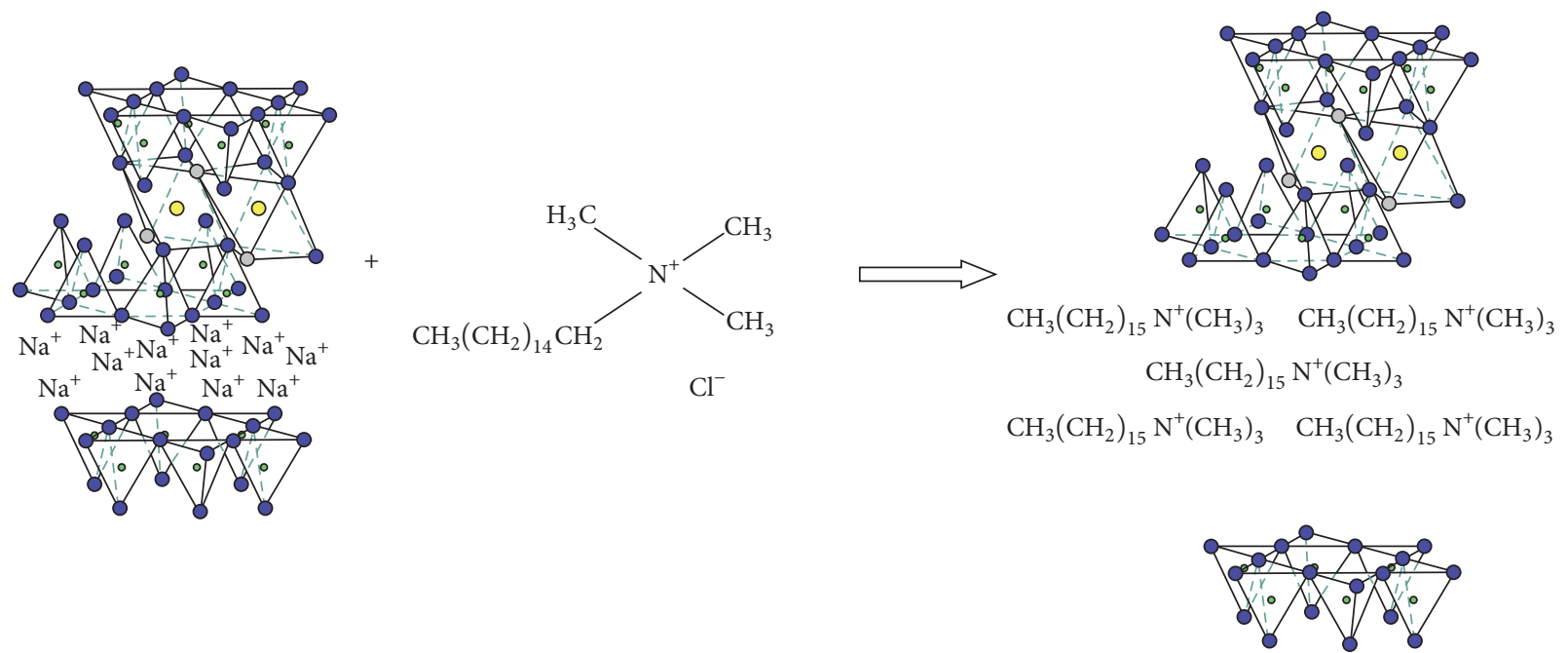

FIGURE 1: Scheme of organobentonite synthesis.

However, it is very difficult to achieve full dispersion of clay inside the polymer matrix. To achieve better dispersion, clay may be modified with various cationic surfactants including quaternary ammonium, phosphonium, and imidazolium ions. Organomontmorillonite clays, for example, can be obtained through the ion exchange reaction between cations in basal planes of the clay $\left(\mathrm{Na}^{+}, \mathrm{Ca}^{2+}\right)$ and organic cations. This cation exchange process results in the expansion of the interlayer spacing and an increase in the basal spacing of the MMT [22].

Shah et al. [22] have emphasized that quaternary ammonium salts are commonly used for making organically modified clay because of their versatile functionalization compared to the other siloxane and phosphonium ion-based surface active agents. Moreover, the modification using these surfactants takes place through relatively simple and facile cation exchange process, which makes it a preferred route over the other options.

Thus, studies of organomontmorillonite and organobentonite clays remain relevant at the present time. The major direction of these studies involves the use of listed materials as fillers in polymer matrices and production of composites.

Hydroxyethyl cellulose is one of the best known polymers from the cellulose family of which the hydroxyl groups are replaced by hydroxyethyl groups. It has excellent film forming ability, biocompatibility, and biodegradability which makes it a suitable material for biomedical applications. Composites of natural biopolymers with aluminosilicates are used as packaging materials in the food industry [23]. Furthermore, clays are known to exhibit biological activity; hence, biopolymers modified with inorganic particles on base of MMT can be used to design antimicrobial drugs and matrices for drug delivery.

It should be noted that information relating to physicochemical properties and biological activity of such biopolymers is insufficient. In this connection, purposes of the current paper are synthesis and characterization of the organobentonite powder, production and study of structure, optical, mechanical properties, and antimicrobial action of the HEC/organobentonite composite films.

\section{Materials and Methods}

2.1. Materials. Hydroxyethyl cellulose (Hercules, US) with a molecular weight of 250000 was used as a template to produce the composite films. Organobentonite was used as the filling agent. Bentonite, sodium chloride, and hexadecyl trimethyl ammonium chloride (HDTMA-Cl) for synthesis of organobentonite were purchased from Sigma Aldrich, US.

2.2. Synthesis of Organobentonite Powder. At first, bentonite clay was concentrated with sodium ions. For this purpose, the bentonite batch $(10 \mathrm{~g})$ was immersed into an aqueous solution of $1 \mathrm{M} \mathrm{NaCl}(500 \mathrm{ml})$ by intensive stirring for 72 hours. Resultant suspension was washed by distilled water to remove the chloride-ions, centrifuged, and dried at a temperature of $373 \mathrm{~K}$. HDTMA-Cl was chosen as a surfactant and $50 \mathrm{ml}$ of HDTMA-Cl aqueous solution (20\%) was prepared. Then the prepared HDTMA-Cl solution was gradually added to aqueous solution $(500 \mathrm{ml})$ of bentonite concentrated with sodium ions (above-mentioned) by intensive stirring using the magnetic stirrer for 72 hours. Final product was washed by distilled water, centrifuged, and dried at a temperature of $373 \mathrm{~K}$. Scheme of organobentonite synthesis is represented in Figure 1.

\subsection{Fabrication of the HEC/Organobentonite Composite Films.} The aqueous HEC solutions and HEC/organobentonite solutions were prepared based on different mass ratio and stirred on a magnetic stirrer at a rate of $180 \mathrm{rpm}$ for $72 \mathrm{~h}$ until a homogeneous gel was obtained. The homogeneity of gel was measured using an optical microscope «Boetius» (Germany): gel was homogeneous on the optical level. Then the obtained polymer solutions were casted onto a Teflon substrate followed by keeping at $293 \mathrm{~K}$ for 7 days to remove 
the solvent. By this technique, we prepared five samples of the composite films with various filler percentage $(0.5,1,3,5$, and 10 wt.\%). Unmodified HEC film was made by the solution cast method as well. The samples thickness was in the range of 25-35 $\mu \mathrm{m}$.

2.4. Laser Diffraction. The sizes of the organobentonite particles were determined by a laser particle sizer (Fritsch Analysette 22 Compact, Germany) in the $0.3-300 \mu \mathrm{m}$ range.

\subsection{Low-Temperature Nitrogen Adsorption-Desorption} Isotherms. Porosity of the organobentonite powder was estimated using a low-temperature nitrogen adsorptiondesorption method. Before the adsorption measurements, the samples were degassed for $7 \mathrm{~h}$ at $363 \mathrm{~K}$. Isotherms were recorded at $77 \mathrm{~K}$ by a Quantachrome Nova 1200 surface area analyzer (US). Three measurements were performed for each sample. Analysis of isotherms was carried out using Brunauer-Emmett-Teller (BET), Barrett-Joyner-Halenda $(\mathrm{BJH})$, and Frenkel-Halsey-Hill (FHH) models. The results were represented as mean values \pm standard deviations.

2.6. Optical Microscopy. The prepared samples of the HEC films and the HEC/organobentonite composite films were examined using a DMBA 310 microscope (Motic, Spain).

2.7. Scanning Electron Microscopy (SEM). The HEC films and the HEC/organobentonite composite films were coated with a layer of platinum. Surface morphology of the prepared samples was investigated by JEOL JSM-5400 scanning electron microscope (Japan). All samples were examined using an accelerating beam at a voltage of $10 \mathrm{kV}$.

2.8. X-Ray Diffraction. The crystal structures of the organobentonite powder, the pure HEC films, and the HEC/ organobentonite composites were evaluated with X-ray diffraction measurements on the base of Debye-Scherrer scheme. Wide-range X-ray diffraction patterns of both powder and film samples were obtained using a DRON-UM1 $\mathrm{X}$-ray diffractometer (Russia) equipped with $\mathrm{CuK}_{\alpha}$ radiation $(\lambda=0.154 \mathrm{~nm})$. X-ray diffractometer was modernized for substances in condensed and polycrystalline state. A scan rate of 1 degree/min was used.

The crystallites size, $L$, was determined using the Scherrer equation [25]:

$$
L=\frac{0.94 \lambda}{\beta \cos \theta_{0}},
$$

where $\beta$ is the full width at half maximum and $\theta_{0}$ is the Bragg angle. Interlayer distance, $d$, was calculated using Bragg's law:

$$
2 d \sin \theta_{0}=n \lambda,
$$

where $n$ is the order of reflection.

The Segal method (peak height method) was used to calculate the crystallinity, $x_{\mathrm{cr}}$, of the samples [26]:

$$
x_{\mathrm{cr}}=\frac{I_{200}-I_{\mathrm{am}}}{I_{200}} \text {, }
$$

where $I_{200}$ is the height of the (200) peak, which represents both crystalline and amorphous phases, and $I_{\mathrm{am}}$ is the lowest height between the (200) and (110) peaks, which represents amorphous material only.

2.9. IR Spectroscopy. For infrared (IR) spectroscopy of organobentonite, HEC, and HEC/organobentonite composites, the samples were prepared by dispersing into $\mathrm{KBr}$ and pressing to pellets. Transmission IR spectra were recorded by an Avatar 360 FT-IR ESR spectrometer with Fourier transform (Thermo Nicolet, US) in the wavenumber range of $4000-400 \mathrm{~cm}^{-1}$ with 16 scans and a resolution of $0.9 \mathrm{~cm}^{-1}$.

2.10. Electrokinetic Measurements. A surface charge (zeta potential) of the particle in suspension was measured by dynamic light scattering using a ZetaSizer Nano system (Malvern Instruments Inc., UK). For this purpose, bentonite and organobentonite powders were dispersed in water with neutral $\mathrm{pH}$ value.

2.11. Mechanical Tests. Tensile properties of both pure HEC films and HEC filled with organobentonite particles were measured under the conditions of uniaxial extension using the UTS 10 universal testing machine (UTStestsysteme, Germany). Before mechanical testing, the samples were kept in a desiccator for one day. For measurements, the films were cut into strips $(2 \mathrm{~mm} \times 20 \mathrm{~mm})$ and then fixed between upper and lower platen of the tensile tester. Tests were conducted at the strain rate of $20 \mathrm{~mm} / \mathrm{min}$. The tensile strength, $\sigma$, and the breaking elongation, $\varepsilon$, were determined tacking into account the film thickness. No less than five tests were performed for each sample. The results have been represented as mean values \pm standard deviations.

2.12. Microbiological Assays. Antimicrobial activity of the HEC films and the HEC/organobentonite composite films was screened against Gram-positives bacteria Staphylococcus aureus Rosenbach 209-P and fungi association consisting of Aspergillus niger F-2481, Cladosporium gossipicola Pidopl F1902, and Cladosporium resinae Albida F-2034. Bacterial and fungal cultures were purchased from All-Russian collection of microorganisms-VKM (Moscow, Russia).

Study of bacteriostatic effect was performed by KirbyBauer disk diffusion method $[27,28]$ that was as follows. We have inoculated an aqueous suspension bacterial spores into the nutrient medium melted and cooled down to $45-50^{\circ} \mathrm{C}$. Concentrations of bacterial spores were equal to $2 \cdot 10^{6} \mathrm{CFU} / \mathrm{ml}$. Plain agar was used as a nutrient medium. A bacterial mixture was prepared using a turbidity standard. The mixture was then thoroughly blended and poured into Petri dishes that were placed on a strictly horizontal surface. After whole congelation, we put the test film specimens on the surface of congealed mixture and placed Petri dishes into a desiccator, in the bottom of which distilled water is poured. Then we placed the desiccator into the thermostat at a temperature of $30 \pm 2^{\circ} \mathrm{C}$ for 24 hours.

Other method was used to evaluate the stability of studied polymer materials against fungi association. We have placed 
TABLE 1: Quantitative adjectives of the particle-size distributions for the researched powders.

\begin{tabular}{lccccc}
\hline \multirow{2}{*}{ Powder } & Mode & Average & \multicolumn{3}{c}{ Sizes relating to } \\
& $(\mu \mathrm{m})$ & size $(\mu \mathrm{m})$ & $10 \%$ & $50 \%$ & $90 \%$ \\
\hline Organobentonite & 63.9 & 74.8 & 20.4 & 69.4 & 127.6 \\
Bentonite $^{*}$ & 5.6 & 3.2 & 1.5 & 4.0 & 7.9 \\
\hline
\end{tabular}

* Parameters for bentonite were found previously [24].

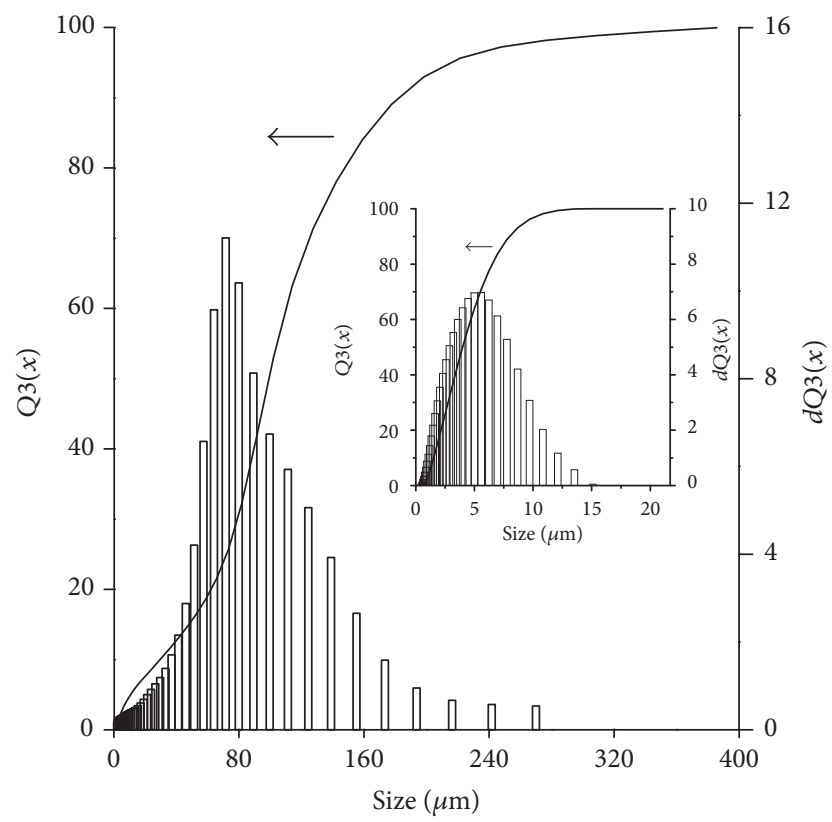

Figure 2: Profile and bar chart of particle-size distribution for the organobentonite powder and bentonite (in insertion).

the test film sample on the sterile Petri dish bottom and applied a fungus suspension onto it. Then we have put Petri dish into a desiccator, in the bottom of which distilled water is poured, and put the desiccator into the thermostat at a temperature of $30 \pm 2^{\circ} \mathrm{C}$. Duration of tests was 28 days. Every 7 days we have opened the cover of the desiccator for the air intake and conducted a preliminary examination of the samples.

Finishing the experiences (in 24 hours for bacteria and in 28 days for fungi), we took the film samples and assessed stability against microorganisms.

\section{Results and Discussion}

\subsection{Characterization of Organobentonite Powder}

3.1.1. Granulometric Composition. Figure 2 shows the results of the laser diffraction for organomodified clay and bentonite (in insertion). The quantitative adjectives of the particle-size distributions are represented in Table 1.

It can be seen that organobentonite predominantly contains particles less than $250 \mu \mathrm{m}$ in diameter. Size distribution is monomodal with peak at $63.9 \mu \mathrm{m}$. On base of data
TABLE 2: Quantitative parameters of porous structure for bentonite and organobentonite powders.

\begin{tabular}{lcc}
\hline Parameter & Organobentonite & Bentonite $^{*}$ \\
\hline$S_{\mathrm{BET}}\left(\mathrm{m}^{2} / \mathrm{g}\right)$ & 25 & 58 \\
$S_{\mathrm{BJH}}\left(\mathrm{m}^{2} / \mathrm{g}\right)$ & 19 & 45 \\
$V_{T}\left(\mathrm{~cm}^{3} / \mathrm{g}\right)$ & 0.040 & 0.101 \\
$D_{\text {av }}(\mathrm{nm})$ & 6.28 & 6.98 \\
$D_{\text {prob }}(\mathrm{nm})$ & 4.05 & 4.03 \\
$d_{f}$ & 2.65 & 2.76 \\
\hline
\end{tabular}

${ }^{*}$ Parameters for bentonite were found previously [24].

analysis, it can be concluded that modification of bentonite by HDTMA-Cl results in a considerable enlargement of particles: the mode (maximum of particle-size distribution) increases from 5.6 to $63.9 \mu \mathrm{m}$; the average size rises from 4.5 to $74.8 \mu \mathrm{m}$. From the cumulative distributions, the sizes corresponding to $10 \%, 50 \%$, and $90 \%$ of particles population were determined. These values have been listed in Table 1, too. The findings also demonstrate that the organobentonite particles are larger compared to basic bentonite.

3.1.2. Porous Structure. In order to determine the structural and adsorption parameters of organobentonite powder, the nitrogen adsorption/desorption isotherm was recorded. We concluded that the observed isotherm was of type II (Figure 3(a)), and synthesized powder was found as material with mesopores [29].

Analysis of the recorded isotherm was carried out using Brunauer-Emmett-Teller (BET), Barrett-Joyner-Halenda (BJH), and Frenkel-Halsey-Hill (FHH) models [30-34]. Figure $3(\mathrm{~b})$ shows the pore size distribution for organobentonite powder that is plotted using the $\mathrm{BJH}$ model. It can be seen that it is monomodal. A specific surface area was determined from isotherm using both BET and FJH models $\left(S_{\mathrm{BET}}\right.$ and $S_{\mathrm{BJH}}$, resp.).

Previously in [24], we reported on researches the porous structure of bentonite. The results are shown in Figures 3(c) and $3(\mathrm{~d})$. Table 2 shows the following numerical parameters of porous structure determined for organobentonite powder, as well for bentonite [24]:

$V_{T}$ is the total pore volume defined as the volume of liquid nitrogen corresponding to the amount adsorbed at a relative pressure of $P / P_{0}=0.99$.

$D_{\mathrm{av}}$ is the average pore diameter.

$D_{\text {prob }}$ is the most probable pore diameter corresponding to the peak of the pore size distribution.

$d_{f}$ is the surface fractal dimension of porous material.

It can be seen in Table 2 that for modified clay the specific surface area and the total pore volume are much less than for pure bentonite. Apparently, the reason for this effect is that the HDTMA-Cl particles fill the pores of the clay, resulting in reduced interface area. It should be noted that the pore filling behavior does not change the position of the distribution maximum when filling. But for organobentonite powders, the average pore size is smaller than for pure bentonite. This 

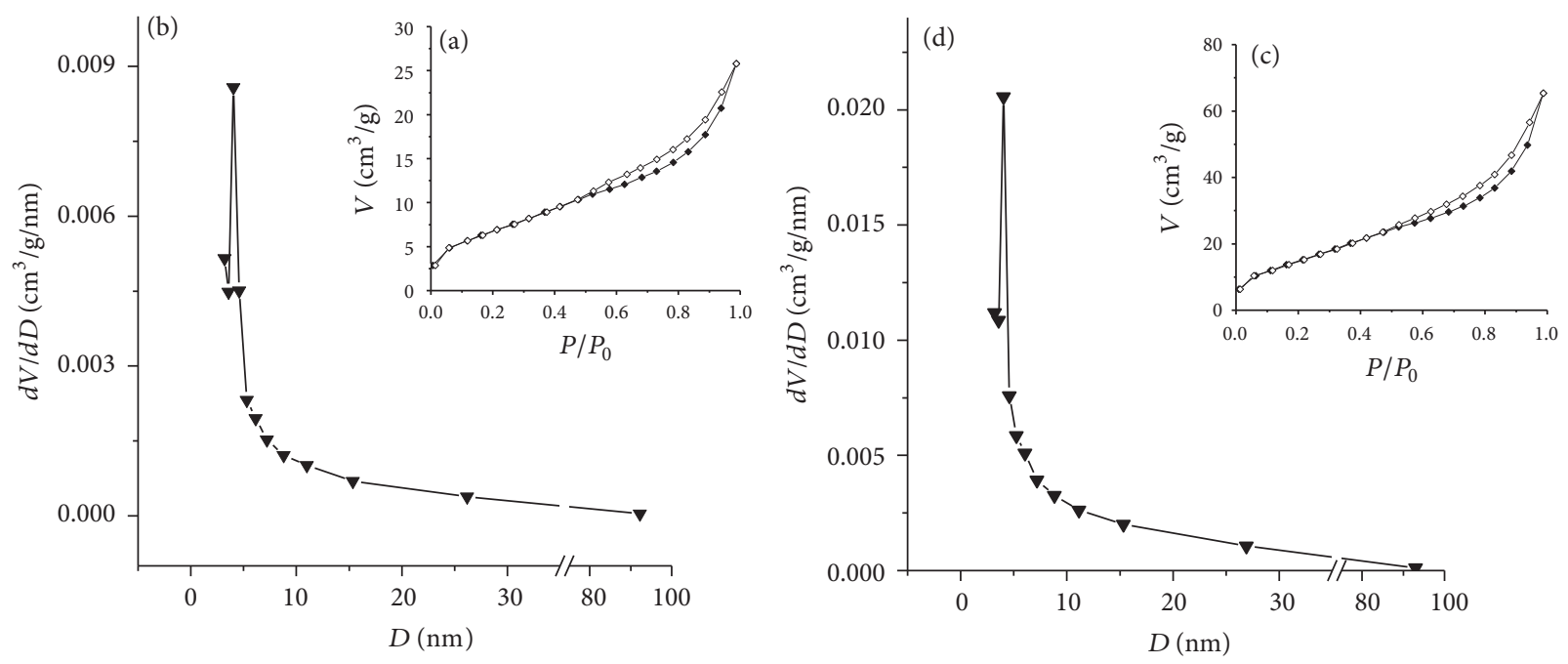

FIGURE 3: Isotherms of low-temperature nitrogen adsorption-desorption for organobentonite (a) and bentonite (c). BJH pore size distribution for organobentonite (b) and bentonite (d).

means that fraction of the large-dimension pores is reduced due to modification of clay with the surfactant particles. Conclusion on reduction of the specific surface area because of filling with the HDTMA-Cl particles is consistent with the data reported by Shah et al. [22] for montmorillonite modified with some quaternary ammonium surfactants.

To quantitatively evaluate the heterogeneities of surface, the fractal FHH model [34] was applied. Namely, data of lowtemperature nitrogen adsorption/desorption were utilized to determine the surface fractal dimension of porous material, $d_{f}$, taking into account the adsorbate surface tension effects. As can be seen in Table 2, for organobentonite, $d_{f}$ value is less than for pure bentonite. That is, the modification of clay with the HDTMA-Cl particles results in smoothing of the surface.

3.1.3. Zeta Potential of the Bentonite and Organobentonite Particles in Suspensions. In order to prove the structural modification on surface of clay by the adsorption of HDTMA-Cl, zeta potential measurement was performed and the surface charge of the particles was determined.

The zeta potential value of bentonite was found to be $-30.6 \mathrm{mV}$ indicating that its surface is negatively charged. But the modification of clay with HDTMA-Cl resulted in a shift in the $\zeta$-potential value nearly $100 \mathrm{mV}$, so that the surface of the particles becomes positively charged $(+67.3 \mathrm{mV})$. This effect is caused by the incorporation of the positively charged surfactant particles in the clay interlayer space. Such large value of the zeta potential is pointed to the strong stability of the colloidal system.

\subsection{Structure and Properties of Hydroxyethyl Cellulose \\ Filled with Organobentonite}

3.2.1. Surface Morphology. Optical microscopy and scanning electron microscopy were used to analyze the distribution of the modified clay particles in the polymer matrix. Figure 4 shows the obtained micrographs for pure HEC and HEC/ organobentonite composite containing $3 \mathrm{wt} \%$ of filler. As seen in Figure 4(a), the surface of pure polymer is smooth, without any distinctive features; that is, the films are homogeneous on the optical level. Figure 4(b) shows that, in the HEC film with $3 \mathrm{wt} . \%$ of organobentonite, the filler particles with various sizes and shapes are fairly evenly distributed.

The data obtained by optical microscopy are consistent with the results of SEM (Figure 5). Polymer film without organoclay shows clear and smooth surface morphology. In contrast, in films filled with $3 \mathrm{wt} . \%$ of organobentonite, good dispersion of filler particles in HEC matrix can be observed, but also agglomerates with varying size are noticed (Figure 5(b)).

3.2.2. Crystal Structure. Figure 6 shows the X-ray diffraction patterns of organobentonite and bentonite (reported previously [24]). The XRD pattern of bentonite (a) contains a wellpronounced reflection at $2 \theta=7^{\circ}$, which corresponds to a distance between aluminosilicate basal surfaces of $1.26 \mathrm{~nm}$. This characteristic peak is assigned to the (001) plane in a good agreement with a reference pattern for montmorillonite (JCPDS card number 29-1498). Modification of bentonite by the HDTMA-Cl particles results in displacement of the reflection (001) towards $2 \theta=4.14^{\circ}$ (Figure $6(\mathrm{~b})$ ) and increase in the interplanar distance from 1.26 to $2.13 \mathrm{~nm}$ (Table 3 ). This conclusion is consistent with the data of $[22,35]$ in which the montmorillonite clays modified with quaternary ammonium salts were researched.

The crystallite size, $L$, determined by (2), for organobentonite $(9.30 \mathrm{~nm})$ is larger than for pure bentonite $(5.73 \mathrm{~nm})$. It indicates the incorporation of the HDTMA-Cl particles into clay crystal grains.

Using X-ray analysis, we also received information on the structural changes taking place in formation of polymer composites.

Figure 7 shows the $\mathrm{X}$-ray diffraction patterns of pure HEC and HEC/organobentonite composites. Pure HEC film 


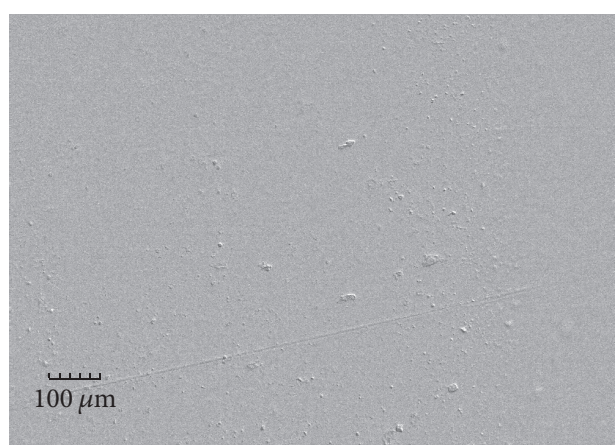

(a)

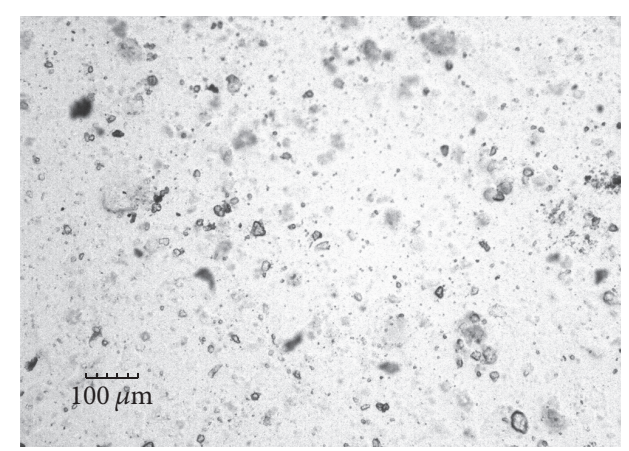

(b)

FIgURE 4: Optical micrographs of the HEC films filled with organobentonite, wt.\% of filler: (a) - 0; (b) - 3.

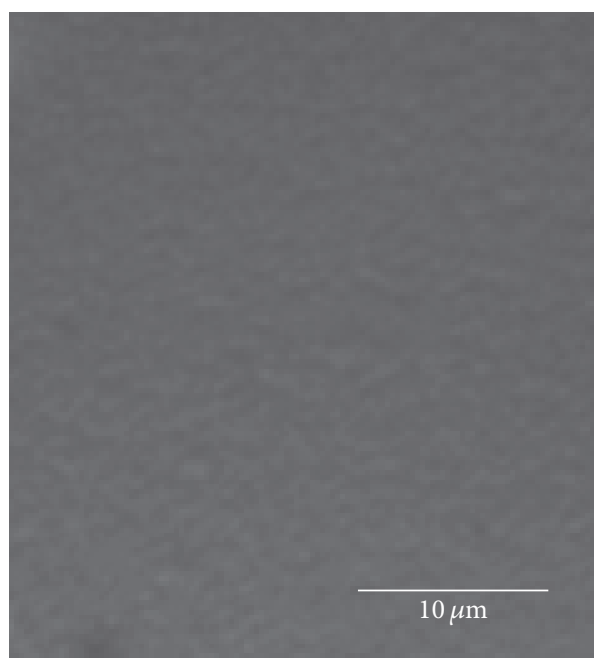

(a)

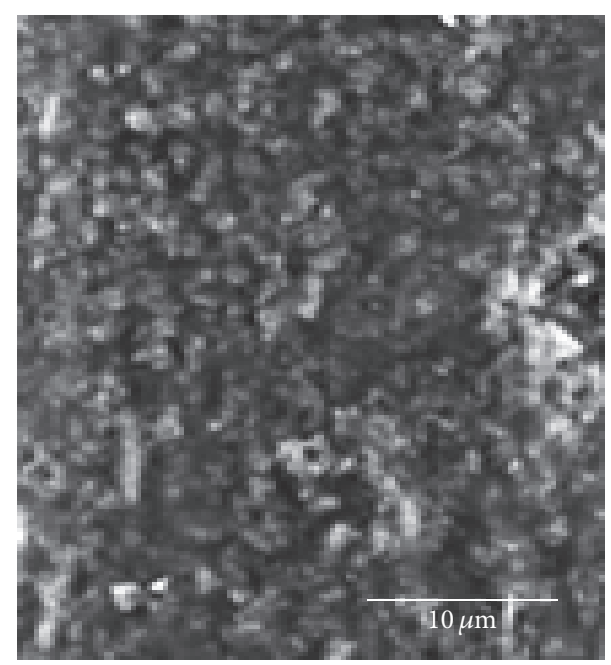

(b)

Figure 5: SEM images of the HEC films filled with organobentonite, wt.\% of filler: (a) - 0; (b) - 3 .

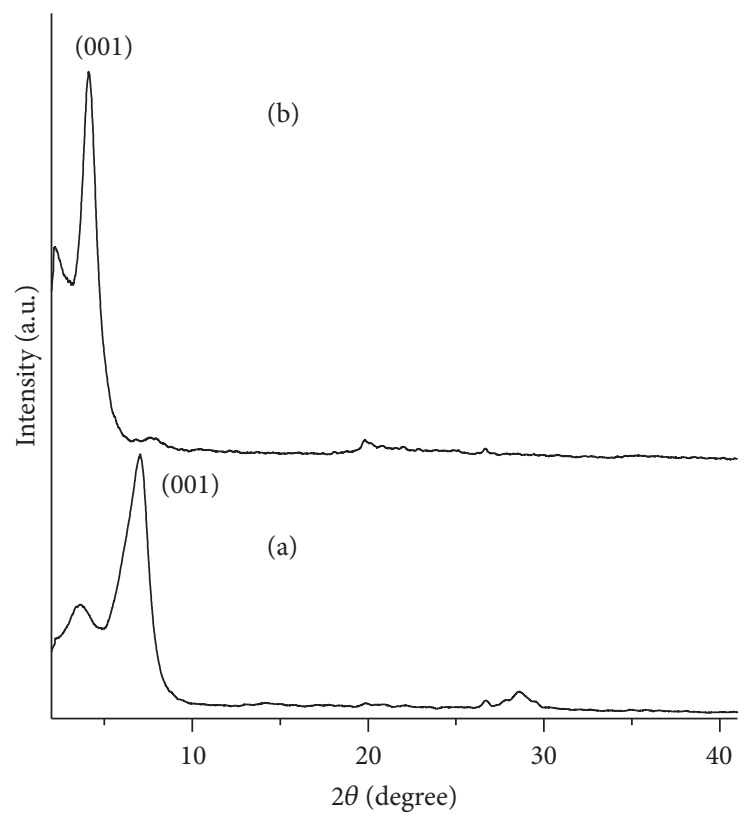

FIGURE 6: XRD patterns for bentonite (a) and organobentonite (b). 
TABLE 3: Results of XRD analysis for bentonite and organobentonite powders.

\begin{tabular}{lcccc}
\hline Powder & $2 \theta_{0}(\mathrm{deg})$ & $\beta(\mathrm{deg})$ & $d(\mathrm{~nm})$ & $L(\mathrm{~nm})$ \\
\hline Organobentonite $^{*}$ & 4.14 & 0.85 & 2.13 & 9.30 \\
Bentonite $^{*}$ & 7.02 & 1.45 & 1.26 & 5.73 \\
\hline
\end{tabular}

${ }^{*}$ Parameters for bentonite were found previously [24].

TABLE 4: Structural-crystal characteristics of the HEC/organobentonite composite films.

\begin{tabular}{|c|c|c|c|c|}
\hline Material & $2 \theta_{0}(\mathrm{deg})$ & $d(\mathrm{~nm})$ & $L(\mathrm{~nm})$ & $x_{\mathrm{cr}}$ \\
\hline HEC/organobentonite (0.5 wt.\%) & 4.64 & 1.90 & 9.7 & 0.76 \\
\hline HEC/organobentonite (1 wt.\%) & 4.47 & 1.97 & 10.0 & 0.93 \\
\hline HEC/organobentonite (5 wt.\%) & 4.34 & 2.03 & 11.2 & 0.90 \\
\hline
\end{tabular}

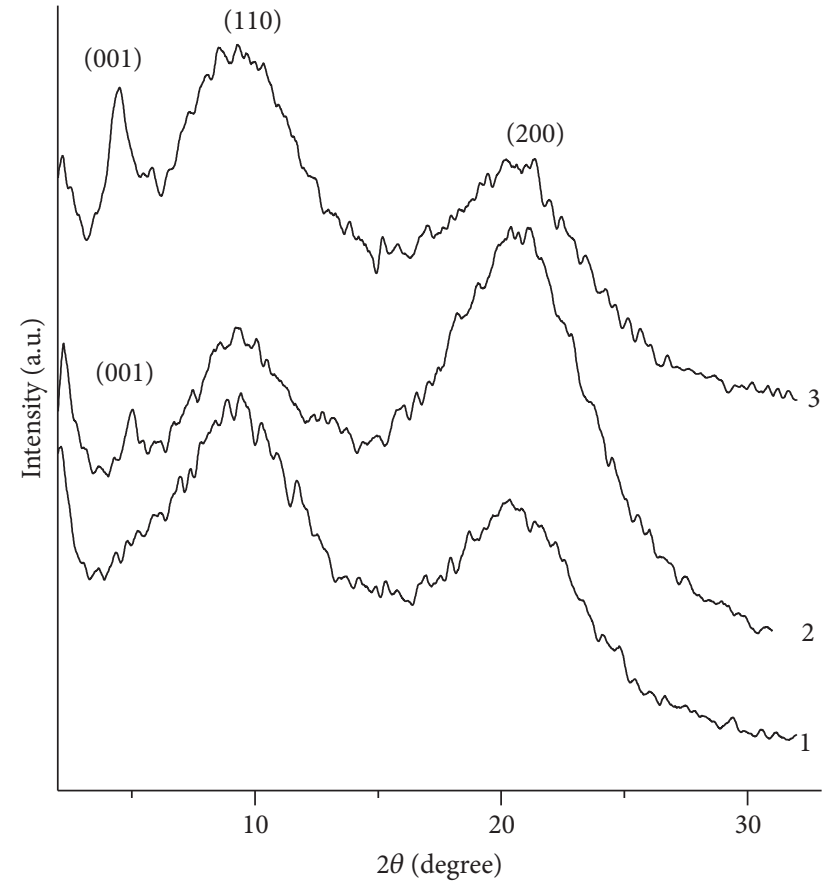

FIGURE 7: XRD patterns for HEC (1), HEC/bentonite (1 wt.\% of filler) composite films (2), and HEC/organobentonite (1wt.\% of filler) composite films (3).

shows the presence of two broad diffraction maxima (halo) centered at $2 \theta=9^{\circ}-10^{\circ}$ and $20^{\circ}$ (Figure 7 , pattern 1), which are typical for the semicrystalline structure of this polymer $[36,37]$. The absence of HEC reflection at angles smaller than $8^{\circ}$ allows one to detect structural changes of filler in the composite film. In the diffractograms for $\mathrm{HEC} /$ bentonite and HEC/organobentonite (patterns 2 and 3), the reflections at $2 \theta$ $=4^{\circ}-5^{\circ}$ appear which indicates the presence of crystal filler in composite material.

It was shown above that the modification of bentonite by HDTMA-Cl resulted in increase in the interlayer distance and average crystallite size in clay (Table 3). We can therefore expect that the structural-crystal characteristics of HEC/organobentonite composites will be different from the same characteristics for HEC/bentonite composites. Figure 7 shows this difference: intensity of the aluminosilicate reflection (001) in pattern 3 is significantly higher than in pattern 2. Note for HEC/organobentonite composites that the crystallites size, $L$, and the interlayer distance, $d$, calculated by (1) and (2), respectively, increase with the filler content (Table 4). Also, Table 4 shows the crystallinity values of the polymer composite as a function of the filler concentration determined by the Segal method. However, there are no distinct trends. It can be assumed that this is due to the insufficient accuracy of the Segal method [38].

3.2.3. Tensile Strength. The tensile strength and the breaking elongation for the produced HEC/organobentonite composite films were found to be comparable to those of pure hydroxyethyl cellulose. It can be seen in Figure 8 that insertion of filler (up to $3 \mathrm{wt} . \%$ ) into the hydroxyethyl cellulose matrix resulted in growth in tensile strength. Further increase in the filler concentration (up to $5 \mathrm{wt} . \%$ ) reduced the $\sigma$ value, possibly due to aggregation of the aluminosilicate particles. It should be noted that similar nonmonotonic dependence of tensile strength on the modified agent concentration was reported by Alexandre and Dubois [39] for the polyimide matrix filled with montmorillonite (main component of bentonite).

Also Figure 8 shows increase in breaking elongation for films when the organobentonite content grows. Therefore, it is of great significance since it indicates the way to increase the deformability of polymer materials on base of hydroxyethyl cellulose.

The data obtained in this study are important in determining the filler concentration range that is permissible in the operation of polymer films.

3.2.4. Infrared Spectroscopy. Interaction between hydroxyethyl cellulose and filler can be investigated by analyzing the IR spectra of organobentonite, HEC, and HEC/ organobentonite composite which are represented in Figure 9 .

The IR spectrum of organobentonite (Figure 9, spectrum 1) displays bands at 3630 and $3400 \mathrm{~cm}^{-1}$ in the hydroxyl $(-\mathrm{OH})$ stretching vibration region. The band at $3630 \mathrm{~cm}^{-1}$ is attributed to $\mathrm{Me}-\mathrm{OH}(\mathrm{Me}=\mathrm{Si}, \mathrm{Mg}$, or $\mathrm{Al})$ bonds, and the last broad one is attributed to hydrogen-bonded interlayer/adsorbed water. In the spectrum of organobentonite, 


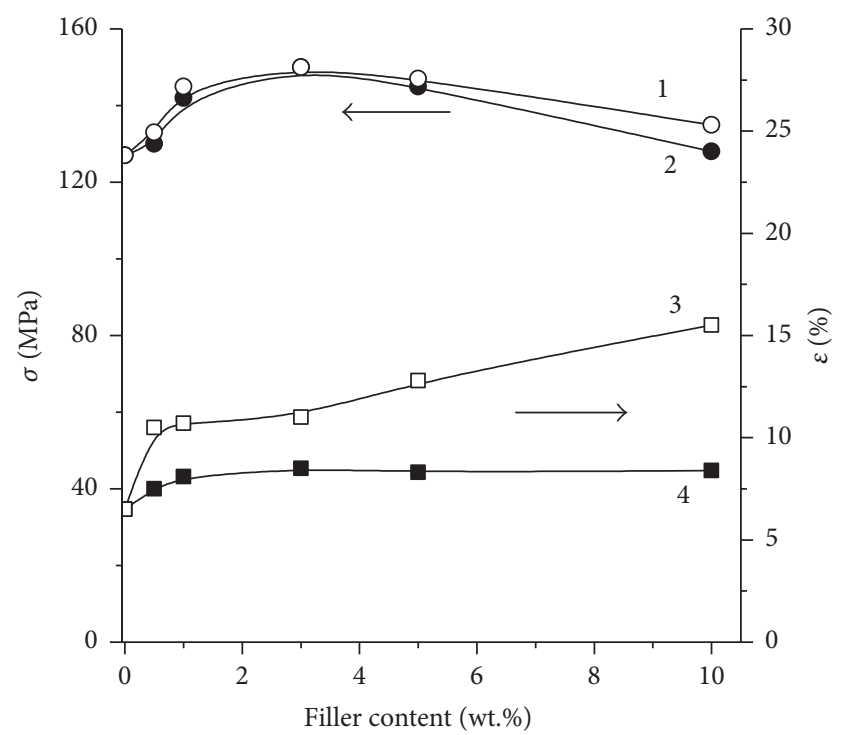

FIGURE 8: Concentration dependence of the tensile strength (1, 2) and the breaking elongation $(3,4)$ for HEC/bentonite (solid symbols) and HEC/organobentonite (open symbols) composite films.

there are bands at 2924 and $2851 \mathrm{~cm}^{-1}$, which are assigned to the antisymmetric and symmetric stretching vibrations of methylene groups $\left(-\mathrm{CH}_{2}-\right)$ of the modifier aliphatic chains. In addition, there is also a sharp $\left(-\mathrm{CH}_{2}-\right)$ bending vibration band at $1475 \mathrm{~cm}^{-1}$ [22]. the band at $1640 \mathrm{~cm}^{-1}$ belongs to the bending vibrations of the adsorbed $\mathrm{H}_{2} \mathrm{O}$ molecules. The intense broad band with the maximum at $1042 \mathrm{~cm}^{-1}$ corresponds to the $\mathrm{Si}-\mathrm{O}-\mathrm{Si}$ stretching vibrations of the $\mathrm{SiO}_{4}$ tetrahedra in the silicon-oxygen framework [40]. The band at $917 \mathrm{~cm}^{-1}$ is assigned to a vibration mode of $\mathrm{Me}-\mathrm{O}-\mathrm{Me}^{*}(\mathrm{Me}$, $\mathrm{Me}^{*}=\mathrm{Mg}, \mathrm{Al}$ or Si) and the bands at 523 and $469 \mathrm{~cm}^{-1}$ are assigned to $\mathrm{Si}-\mathrm{O}-\mathrm{Si}$ bending mode [41]. The narrow band at $796 \mathrm{~cm}^{-1}$ corresponds to bending vibrations of silanol groups $[42,43]$.

The IR spectrum of the pure HEC film (Figure 9, spectrum 2) displays the broad band in the range of $3700-3000 \mathrm{~cm}^{-1}$ (maximum at $3423 \mathrm{~cm}^{-1}$ ) which is attributed to $\mathrm{OH}$ stretching mode. These hydroxyl groups are not free but enter into different modes of hydrogen bonds. In the absorption range of $3000-2800 \mathrm{~cm}^{-1}$, there are $\mathrm{CH}$ stretching vibrations of $\mathrm{CH}_{3}$ and $\mathrm{CH}_{2}$ groups. The absorption band at $1651 \mathrm{~cm}^{-1}$ corresponds to adsorbed water. The band at $1458 \mathrm{~cm}^{-1}$ contains the bending planar vibrations of the $\mathrm{C}-\mathrm{H}$ and $\mathrm{O}-\mathrm{H}$ bonds. The band at $1430 \mathrm{~cm}^{-1}$ contains the bending vibrations of the $\mathrm{CH}_{2}$ groups. The band at $1060 \mathrm{~cm}^{-1}$ is assigned to the stretching vibrations of $\mathrm{C}-\mathrm{O}$ bonds in the alcohol and ether groups. Band at $933 \mathrm{~cm}^{-1}$ is attributed to bending vibrations of the $\mathrm{CH}$ groups. The absorption band at $890 \mathrm{~cm}^{-1}$ is assigned to $\mathrm{C}-\mathrm{O}-\mathrm{C}$ stretching at $\beta-(1 \rightarrow 4)$ glycosidic linkages [44-46].

Spectrum 3 in Figure 9 is the IR spectrum of HEC/ organobentonite composite containing $5 \mathrm{wt} . \%$ of filler. It shows the differences in contrast to the spectrum of HEC. The
TABLE 5: Infrared crystallinity and symmetry indexes for pure HEC and HEC/organobentonite composites.

\begin{tabular}{lcc}
\hline Sample & Crystallinity index & Symmetry index \\
\hline Pure HEC & 1.37 & 3.78 \\
HEC/organobentonite & 1.11 & 5.94 \\
\hline
\end{tabular}

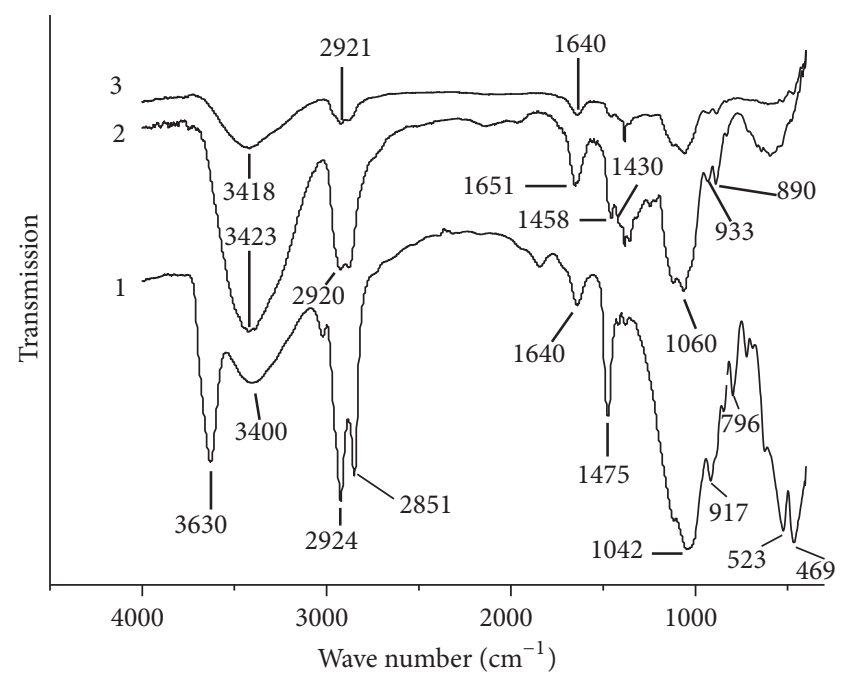

FIGURE 9: IR spectra of organobentonite (1), HEC (2), and HEC/ organobentonite (3).

maximum of band in the region of $3700-3000 \mathrm{~cm}^{-1}$ is shifted by $7 \mathrm{~cm}^{-1}$ towards smaller wave numbers in the composite spectrum.

For the characteristics of these bands in the spectra of HEC and the composite, a symmetry index was used. The symmetry index is defined as the ratio of the left and right sides of the width of the absorption band at $3700-3000 \mathrm{~cm}^{-1}$ (OH-group), measured from the middle of the perpendicular drawn through the maximum of the band. The results are presented in Table 5. The increase in the symmetry index suggests that modification HEC with organoclay reduces the density of hydrogen-bond net of polymer. The maximum of water absorption band $\left(1651 \mathrm{~cm}^{-1}\right)$ is shifted by $11 \mathrm{~cm}^{-1}$ towards smaller wave numbers in the composite spectrum. This indicates a decline in the water concentration in the HEC/organobentonite composite film.

In addition, a crystallinity index was calculated as the ratio of the absorption band at $1430 \mathrm{~cm}^{-1}$ to the band at $890 \mathrm{~cm}^{-1}$ [47] (Table 5). The decrease in the values of the crystallinity index, $D_{1430} / D_{890}$, and the increase in the symmetry index for the HEC/organobentonite composite in comparison with similar characteristics to the unmodified HEC are due to the increase in the proportion of the amorphous regions in the polymer structure when modifying with organoclay.

Note that this conclusion does not correlate with the data of X-ray diffraction (Table 4). Similar mismatch is very common because the crystallinity values highly depend on the measurement method as well as the data analysis [38]. 
TABLE 6: Antibacterial activity of the HEC/organobentonite composite films against $S$. aureus.

\begin{tabular}{lc}
\hline Filler content, wt.\% & Size of the lysis zone $(\mathrm{mm})$ \\
\hline 0 & 0 \\
0.5 & 0 \\
1 & 0 \\
5 & $7 \pm 2$ \\
\hline
\end{tabular}

3.2.5. Antimicrobial Activity. It was noticed above that modification by nanoparticles can result in occurrence of new properties of polymer, for example, biological activity.

In the current paragraph, we describe data of the tests that were performed to compare antimicrobial action of the pure HEC films and HEC/organobentonite composite films. For these purposes, spores of bacterial and fungal cultures were incubated under conditions that are optimal for their growth and development (Section 2.12), and effect of produced films was researched.

Quantitative assessment of bacteriostatic action for the researched film materials against $S$. aureus was performed using width of a lysis zone as a measurable parameter. The lysis zone is the inhibition zone of bacterial growth formed in the nutrient medium. Figures 10(a) and 10(b) display the distinct lysis zone around the sample of the HEC/organobentonite composite film containing $5 \mathrm{wt} . \%$ of filler. But pristine HEC and HEC filled with organobentonite (less than $5 \mathrm{wt} . \%$ ) do not exhibit bacteriostatic action against S. aureus (Table 6). From the data, we can conclude that hydroxyethyl cellulose exhibits bacteriostatic action as a result of doping with organobentonite (no less than $5 \mathrm{wt} . \%$ of filler). Apparently, one of the reasons of microorganisms inactivation is that organobentonite can adsorb the pathogenic bacteria and retain them within composite. This provides a physical barrier against bacterial development.

Antifungal activity of the pure HEC films and the HEC/organobentonite composite films was researched against association of molds listed in Section 2.12. For these purposes, the other method (qualitative) was used. The data presented in Table 7 have indicated that growth of microorganisms was not detected on the surface of all films. So, the pure HEC films and HEC filled with organobentonite have fungal resistance.

Thus, from the biological activity tests of hydroxyethyl cellulose filled with organobentonite, we have found that researched materials have exhibited antimicrobial action against a number of pathogenic bacteria and fungi. It should be noted that choice of these test cultures is due to that these species cause diseases of animals and humans and dominate during the biological corrosion of technical materials.

\section{Conclusion}

In the present paper, organobentonite particles were loaded into the hydroxyethyl cellulose matrix by mechanical dispersion, and composite films were obtained. The findings have
TABLE 7: Biostability of the HEC/organobentonite composite films against molds.

\begin{tabular}{lc}
\hline Filler content (wt.\%) & Test results \\
\hline 0 & - \\
0.5 & - \\
1 & - \\
5 & - \\
\hline
\end{tabular}

-Growth of microorganisms was not detected.

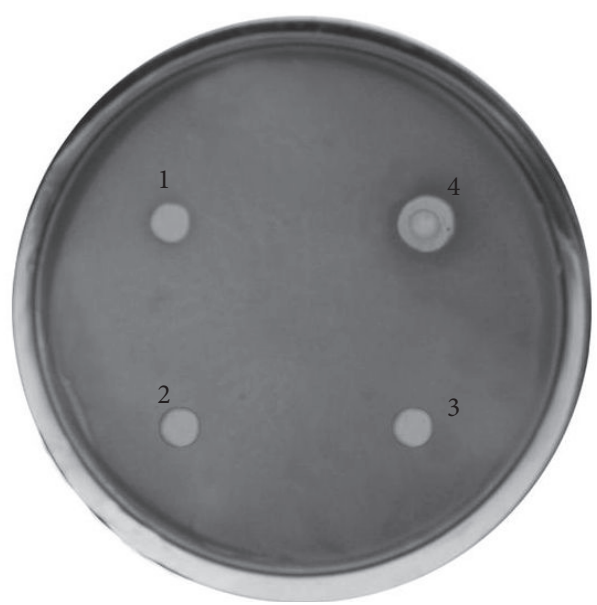

(a)

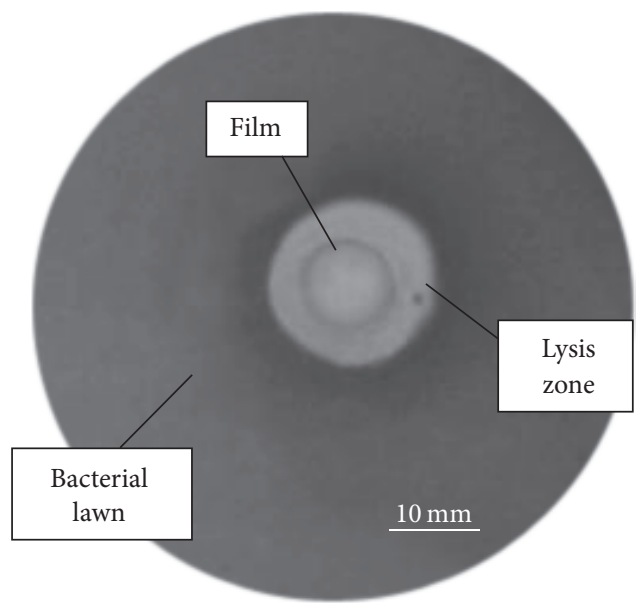

(b)

FIGURE 10: Effect of the filler concentration in the HEC/ organobentonite composite films on inhibition of $S$. aureus growth: (a) HEC/organobentonite composite films with various filler concentrations, wt.\%: 0 (1), 0.5 (2), 1 (3), and 5 (4); (b) HEC/organobentonite composite film with $5 \mathrm{wt} . \%$ of filler (on an enlarged scale).

shown that organobentonite proved to be quite effective modifiers for hydroxyethyl cellulose. Effect of the filler concentration on the structure and mechanical properties of polymer films was detected. It was found that HEC/organobentonite films can inhibit the growth of a number of pathogenic bacteria and fungi. The resulting data will provide better understanding of the preparation principles for such composites and formulation of new ideas and approaches that 
can give additional stimulus to the development of advanced technologies.

\section{Conflicts of Interest}

The authors declare that there are no conflicts of interest regarding the publication of this paper.

\section{Acknowledgments}

The study was supported by the Russian Foundation for Basic Research (Project no. 15-43-03034-a).

\section{References}

[1] M. R. Ayatollahi, S. Shadlou, and M. M. Shokrieh, "Multiscale modeling for mechanical properties of carbon nanotube reinforced nanocomposites subjected to different types of loading," Composite Structures, vol. 93, no. 9, pp. 2250-2259, 2011.

[2] K. Chen, C. A. Wilkie, and S. Vyazovkin, "Nanoconfinement revealed in degradation and relaxation studies of two structurally different polystyrene-clay systems," Journal of Physical Chemistry B, vol. 111, no. 44, pp. 12685-12692, 2007.

[3] S. D. Burnside and E. P. Giannelis, "Nanostructure and properties of polysiloxane-layered silicate nanocomposites," Journal of Polymer Science, Part B: Polymer Physics, vol. 38, no. 12, pp. 1595-1604, 2000.

[4] E. Kontou and M. Niaounakis, "Thermo-mechanical properties of $\mathrm{LLDPE} / \mathrm{SiO}_{2}$ nanocomposites," Polymer, vol. 47, no. 4, pp. 1267-1280, 2006.

[5] A. Lazzeri, S. M. Zebarjad, M. Pracella, K. Cavalier, and R. Rosa, "Filler toughening of plastics. Part 1-the effect of surface interactions on physico-mechanical properties and rheological behaviour of ultrafine $\mathrm{CaCO}_{3} / \mathrm{HDPE}$ nanocomposites," Polymer, vol. 46, no. 3, pp. 827-844, 2005.

[6] O. V. Alekseeva, V. P. Barannikov, N. A. Bagrovskaya, and A. V. Noskov, "DSC investigation of the polystyrene films filled with fullerene," Journal of Thermal Analysis and Calorimetry, vol. 109, no. 2, pp. 1033-1038, 2012.

[7] O. V. Alekseeva, V. N. Rudin, I. V. Melikhov, N. A. Bagrovskaya, S. M. Kuzmin, and A. V. Noskov, "Kinetics of formation of hierarchical nanostructures in polystyrene films containing fullerene," Doklady Physical Chemistry, vol. 422, no. 2, pp. 275278, 2008.

[8] O. V. Alekseeva, N. A. Bagrovskaya, S. M. Kuzmin, and A. V. Noskov, "Study of structural properties of polystyrene-fullerene composites," Journal of the Balkan Tribological Association, vol. 16, no. 4, pp. 558-563, 2010.

[9] O. V. Alekseeva, A. V. Noskov, S. S. Guseinov, and A. V. Agafonov, "The effect of silicon dioxide concentration on thermodynamic properties of polystyrene-based composites," Protection of Metals and Physical Chemistry of Surfaces, vol. 51, no. 2, pp. 253-256, 2015.

[10] O. V. Alekseeva, A. N. Rodionova, N. A. Bagrovskaya, A. V. Agafonov, and A. V. Noskov, "Hydroxyethyl cellulose/bentonite/magnetite hybrid materials: structure, physicochemical properties, and antifungal activity," Cellulose, vol. 24, no. 4, pp. 1825-1836, 2017.

[11] A. M. Bochek, N. M. Zabivalova, I. V. Gofman, V. E. Yudin, V. K. Lavrent'Ev, and I. V. Abalov, "Properties of cellulose solutions in methylmorpholine N-oxide containing montmorillonite nanoparticles and of composite films thereof," Russian Journal of Applied Chemistry, vol. 84, no. 7, pp. 1261-1265, 2011.

[12] S. Tunç and O. Duman, "Preparation and characterization of biodegradable methyl cellulose/montmorillonite nanocomposite films," Applied Clay Science, vol. 48, no. 3, pp. 414-424, 2010.

[13] A. Arora, V. Choudhary, and D. K. Sharma, "Effect of clay content and clay/surfactant on the mechanical, thermal and barrier properties of polystyrene/organoclay nanocomposites," Journal of Polymer Research, vol. 18, no. 4, pp. 843-857, 2011.

[14] F. Bergaya, B. K. G. Theng, and G. Lagaly, Handbook of Clay Science, vol. 1, Elsevier Ltd, Amsterdam, 2006.

[15] A. Gil, S. A. Korili, and M. A. Vicente, "Recent advances in the control and characterization of the porous structure of pillared clay catalysts," Catalysis Reviews - Science and Engineering, vol. 50, no. 2, pp. 153-221, 2008.

[16] R. J. Sengwa, S. Choudhary, and S. Sankhla, "Dielectric spectroscopy of hydrophilic polymers-montmorillonite clay nanocomposite aqueous colloidal suspension," Colloids and Surfaces A: Physicochemical and Engineering Aspects, vol. 336, no. 1-3, pp. 79-87, 2009.

[17] Z. Zhao, T. Tang, Y. Qin, and B. Huang, "Effects of surfactant loadings on the dispersion of clays in maleated polypropylene," Langmuir, vol. 19, no. 18, pp. 7157-7159, 2003.

[18] R. A. Vaia and E. P. Giannelis, "Lattice model of polymer melt intercalation in organically-modified layered silicates," Macromolecules, vol. 30, no. 25, pp. 7990-7999, 1997.

[19] H. R. Dennis, D. L. Hunter, D. Chang et al., "Effect of melt processing conditions on the extent of exfoliation in organoclaybased nanocomposites," Polymer, vol. 42, no. 23, pp. 9513-9522, 2001.

[20] H. Xiong, S. Tang, H. Tang, and P. Zou, "The structure and properties of a starch-based biodegradable film," Carbohydrate Polymers, vol. 71, no. 2, pp. 263-268, 2008.

[21] H. Liu, D. Chaudhary, S.-I. Yusa, and M. O. Tadé, "Glycerol/ starch/Na+-montmorillonite nanocomposites: A XRD, FTIR, DSC and 1H NMR study," Carbohydrate Polymers, vol. 83, no. 4, pp. 1591-1597, 2011.

[22] K. J. Shah, M. K. Mishra, A. D. Shukla, T. Imae, and D. O. Shah, "Controlling wettability and hydrophobicity of organoclays modified with quaternary ammonium surfactants," Journal of Colloid and Interface Science, vol. 407, pp. 493-499, 2013.

[23] S. Tunç and O. Duman, "Preparation of active antimicrobial methyl cellulose/carvacrol/montmorillonite nanocomposite films and investigation of carvacrol release," LWT - Food Science and Technology, vol. 44, no. 2, pp. 465-472, 2011.

[24] O. V. Alekseeva, A. N. Rodionova, N. A. Bagrovskaya, A. V. Agafonov, and A. V. Noskov, "Effect of the bentonite filler on structure and properties of composites based on hydroxyethyl cellulose," Arabian Journal of Chemistry, 2015.

[25] A. Guinier, X-Ray Diffraction: in Crystals, Imperfect Crystals, and Amorphous Bodies, Dover Publications, New York, NY, USA, 2001.

[26] N. Terinte, R. Ibbett, and K. C. Schuster, "Overview on native cellulose and microcrystalline cellulose I structure studied by $\mathrm{X}$-ray diffraction (waxd): Comparison between measurement techniques," Lenzinger Berichte, vol. no. 89, pp. 118-131, 2011.

[27] H. Zhang, X. Zeng, J. Xie, Z. Li, and H. Li, "Study on the sorption process of triclosan on cationic microfibrillated cellulose and its antibacterial activity," Carbohydrate Polymers, vol. 136, pp. 493498, 2016. 
[28] Y.-J. Tang, X.-F. Liu, J. Xia, G.-X. Xue, and J. Wang, “Preparation of $\mathrm{TiO}_{2} /$ chitosan nanocomposited coatings and its application in antibacterial coated paper," Journal of Functional Materials, vol. 43, no. 17, pp. 2416-2420, 2012.

[29] K. S. Sing, "Reporting physisorption data for gas/solid systems with special reference to the determination of surface area and porosity (Recommendations 1984)," Pure and Applied Chemistry, vol. 57, no. 4, pp. 603-619, 1985.

[30] K. S. W. Sing, "Adsorption methods for the characterization of porous materials," Advances in Colloid and Interface Science, vol. 76-77, pp. 3-11, 1998.

[31] E. P. Barrett, L. G. Joyner, and P. P. Halenda, "The determination of pore volume and area distributions in porous substances. I. Computations from nitrogen isotherms," Journal of the American Chemical Society, vol. 73, no. 1, pp. 373-380, 1951.

[32] K. K. Aligizaki, Pore Structure of Cement-Based Materials: Testing Interpretation and Requirements (Modern Concrete Technology, Taylor and Francis, New York, NY, USA, 2005.

[33] V. Panella and J. Krim, "Adsorbate surface tension effects for isotherms recorded on fractally rough surfaces," in Characterization of Porous Solids III (Studies in Surface Science and Catalysis), J. Rouquerol, F. Rodriguez-Reinoso, K. Sing, and K. Unger, Eds., vol. 87, pp. 3-19, Elsevier Science, Amsterdam, Netherlands, 1994.

[34] P. J. Pomonis and E. T. Tsaousi, "Frenkel-Halsey-Hill equation, dimensionality of adsorption, and pore anisotropy," Langmuir, vol. 25, no. 17, pp. 9986-9994, 2009.

[35] C.-H. Zhou, D. Zhang, D.-S. Tong, L.-M. Wu, W.-H. Yu, and S. Ismadji, "Paper-like composites of cellulose acetate-organomontmorillonite for removal of hazardous anionic dye in water," Chemical Engineering Journal, vol. 209, pp. 223-234, 2012.

[36] A. M. Bochek, I. L. Shevchuk, I. I. Gavrilova et al., "Properties of aqueous solutions of hydroxyethyl cellulose-poly(N- vinylformamide) blends and of the related composite films," Polymer Science-Series A, vol. 54, no. 9, pp. 730-737, 2012.

[37] K. Luo, J. Yin, O. V. Khutoryanskaya, and V. V. Khutoryanskiy, "Mucoadhesive and elastic films based on blends of chitosan and hydroxyethylcellulose," Macromolecular Bioscience, vol. 8, no. 2, pp. 184-192, 2008.

[38] K. Karimi and M. J. Taherzadeh, "A critical review of analytical methods in pretreatment of lignocelluloses: Composition, imaging, and crystallinity," Bioresource Technology, vol. 200, pp. 1008-1018, 2016.

[39] M. Alexandre and P. Dubois, "Polymer-layered silicate nanocomposites: preparation, properties and uses of a new class of materials," Materials Science and Engineering R: Reports, vol. 28, no. 1, pp. 1-63, 2000.

[40] D. Onoshima and T. Imae, "Dendritic nano- and microhydrogels fabricated by triethoxysilyl focal dendrons," Soft Matter, vol. 2, no. 2, pp. 141-148, 2006.

[41] K. C. Cole, "Use of infrared spectroscopy to characterize clay intercalation and exfoliation in polymer nanocomposites," Macromolecules, vol. 41, no. 3, pp. 834-843, 2008.

[42] S. K. Parida, S. Dash, S. Patel, and B. K. Mishra, "Adsorption of organic molecules on silica surface," Advances in Colloid and Interface Science, vol. 121, no. 1-3, pp. 77-110, 2006.

[43] S. Y. Khashirova, Y. I. Musaev, A. K. Mikitaev, Y. A. Malkanduev, and M. K. Ligidov, "Hybrid nanocomposites based on guanidine methacrylate monomer and polymer and layered aluminosilicates: Synthesis, structure, and properties," Polymer Science - Series B, vol. 51, no. 9-10, pp. 377-382, 2009.
[44] J. Blackwell and R. H. Marchessault, "Infrared spectroscopy. Structure studies," in Cellulose and cellulose derivatives. Part IV, N. M. Bikales and L. Segal, Eds., pp. 1-38, Wiley Interscience, New York, NY, USA, 1971.

[45] H. S. Barud, A. M. de Araújo Júnior, D. B. Santos et al., “Thermal behavior of cellulose acetate produced from homogeneous acetylation of bacterial cellulose," Thermochimica Acta, vol. 471, no. 1-2, pp. 61-69, 2008.

[46] J. Dechant, R. Danz, W. Kimmer, and R. Schmolke, "Ultraspectroscopische untersuchungen an polymeren," Akademie Verlag, 1972.

[47] R. T. O'connor, E. F. Dupré, and D. Mitcham, "Applications of infrared absorption spectroscopy to investigations of cotton and modified cottons. Part I: physical and crystalline modifications and oxidation," Textile Research Journal, vol. 28, no. 5, pp. 382392, 1958. 

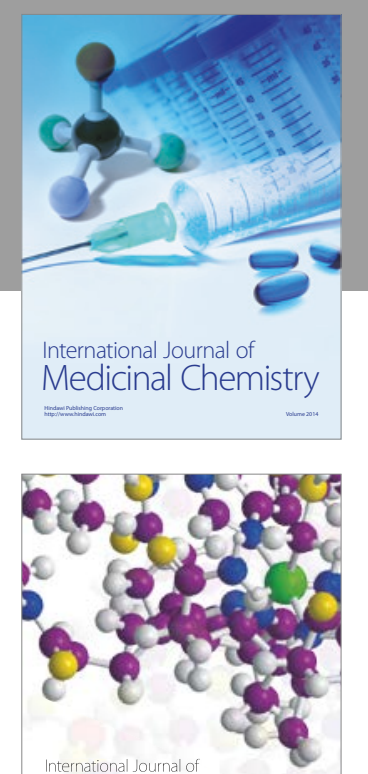

Carbohydrate Chemistry

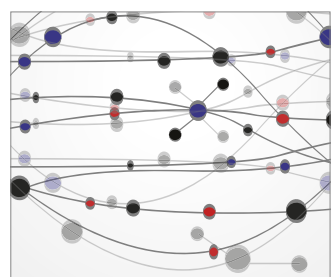

The Scientific World Journal
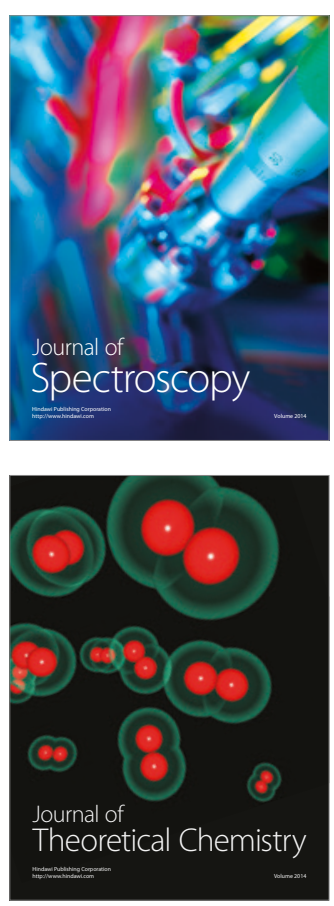
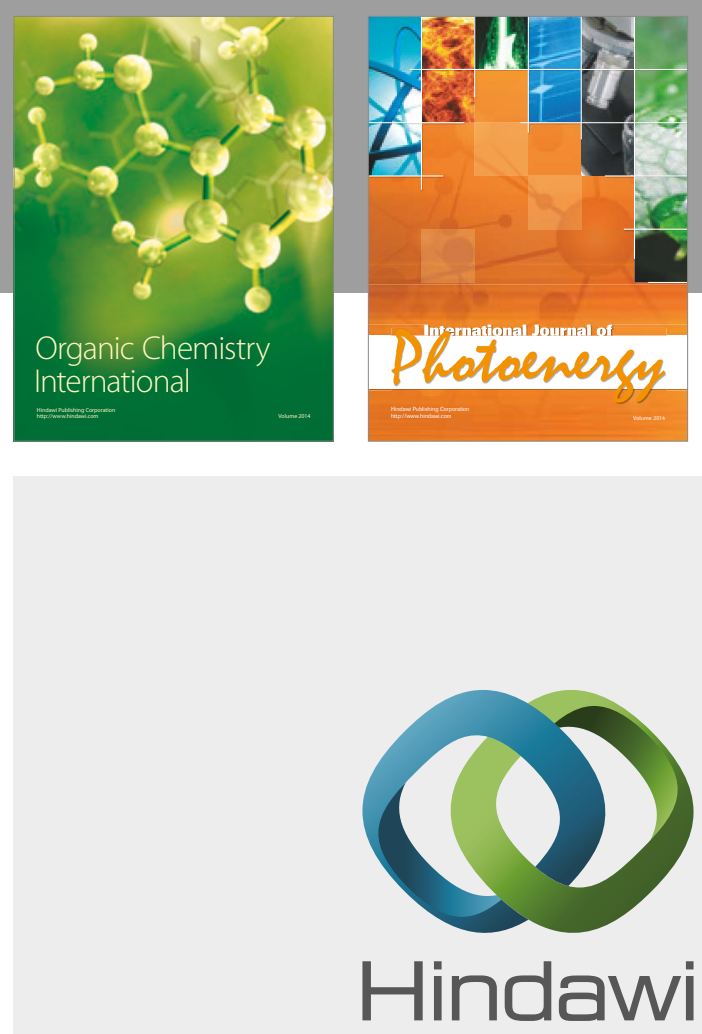

Submit your manuscripts at

https://www.hindawi.com

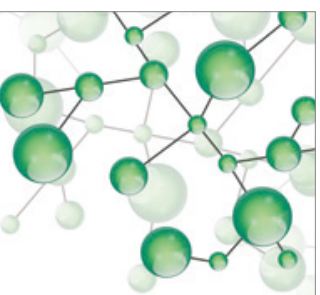

International Journal of

Inorganic Chemistry

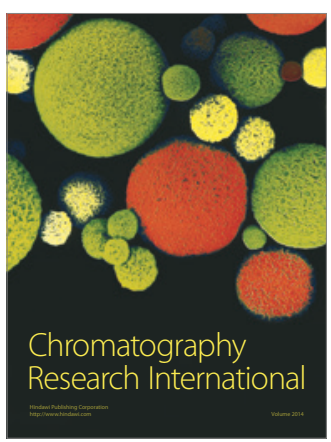

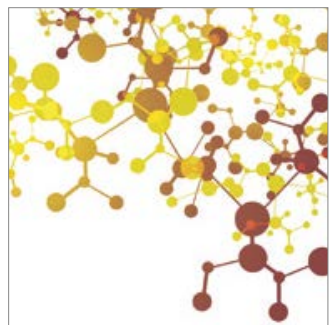

Applied Chemistry
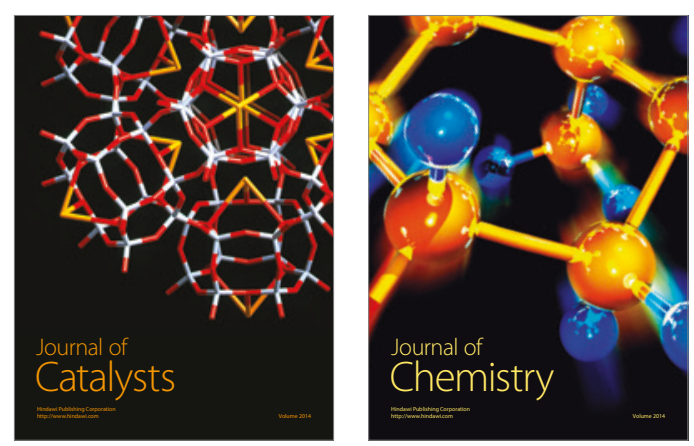
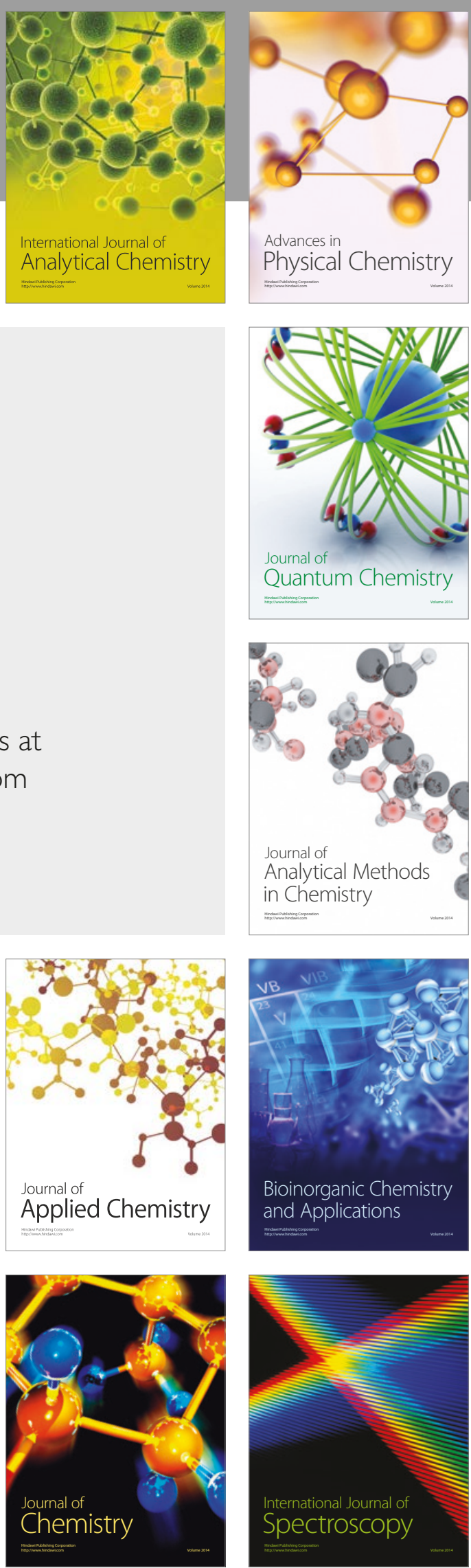